\title{
Analysis of Service Quality at the Regional Financial and Asset Management Office of South Bengkulu Regency
}

\section{Analisis Kualitas Pelayanan pada Dinas Pengelolaan Keuangan dan Aset Daerah Kabupaten Bengkulu Selatan}

\author{
Gustini \\ Sekolah Tinggi Ilmu Administrasi Bengkulu \\ Email: stia_gustini@yahoo.com
}

\section{How to Cite :}

Gustini. (2022). Analysis of Service Quality at the Regional Financial and Asset Management Office of South Bengkulu Regency. Jurnal Ekonomi Manajemen Akuntansi Dan Keuangan, 3(1). DOI: https://doi.org/10.53697/emak.v3i1

\section{ARTICLE HISTORY}

Received [30 Desember 2021]

Revised [04 Januari 2021]

Accepted [25 Januari 2022]

\section{KEYWORDS}

Quality of Service, Society

Satisfaction Index (SSI), Asset

Management

This is an open access article under the $C C-B Y$-SA license

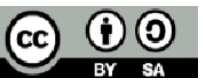

\section{ABSTRAK}

Pelayanan publik oleh aparatur pemerintah di berbagai sektor pelayanan yang berkaitan dengan pemenuhan hak-hak sipil dan kebutuhan dasar dinilai tidak sesuai dengan tuntutan dan harapan masyarakat. Hal itu terlihat antara lain dari banyaknya pengaduan, pengaduan yang disampaikan masyarakat melalui media atau langsung ke kementerian. Untuk itu diperlukan penilaian masyarakatsebagai pelayanan publik oleh pengguna layanan tersebut. Tujuan dari penelitian ini adalah untuk menganalisis kualitas pelayanan yang diberikan oleh Dinas Pengelolaan Keuangan dan Aset Daerah Kabupaten Bengkulu Selatan. Penelitian ini dirancang sebagai penelitian deskriptif. Populasi dalam penelitian ini adalah seluruh masyarakat yang melakukan kegiatan di bidang Dinas Pengelolaan Keuangan dan Aset Daerah Kabupaten Bengkulu Selatan. Sampel dalam penelitian ini sebanyak 150 responden. Teknik pengumpulan data dalam penelitian ini adalah kuesioner. Hasil penelitian menunjukkan bahwa: Pengukuran nilai Indeks Kepuasan Masyarakat (ISIS) secara keseluruhan menunjukkan hal yang positif dan dikategorikan dalam kondisi baik dan baik.

\section{ABSTRACT}

Public services by government officials in various service sectors related to the fulfillment of civil rights and basic needs are considered not in accordance with the demands and expectations of the community. This can be seen, among others, from the number of complaints, complaints submitted by the public through the media or directly to the ministry. For this reason, it is necessary to assess the community as a public service by users of these services. The purpose of this study was to analyze the quality of services provided by the Department of Financial and Asset Management in South Bengkulu Regency. This study was designed as a descriptive study. The population in this study is all people who carry out activities in the field of the Regional Financial and Asset Management Office of South Bengkulu Regency. The sample in this study were 150 respondents. The data collection technique in this study was a questionnaire The results showed that: The overall measurement of the Community Satisfaction Index (ISIS) value showed positive things and was categorized in good and good condition. 


\section{PENDAHULUAN}

Pemerintah Daerah mendapatkan kebijakan otonomi daerah dari desentralisasi fiskal. Bentuk kebijakan tersebut dituangkan ke dalam Undang-undang Nomor 28 Tahun 2009 tentang Pajak Daerah dan Retribusi Daerah. Tingkat kesadaran masyarakat saat ini semakin tinggi. Hak dan kewajibannya sebagai warga negara dalam hidup bermasyarakat, berbangsa, dan bernegara semakin disadari. Perkembangan kehidupan masyarakat yang semakin baik, membuat masyarakat semakin berani untuk menunjukan tuntutan, keinginan dan aspirasinya kepada pemerintah. Mesyarakat berani unntuk mengontrol terhadap kegiatan apa saja yang dilakukan oleh pemerintah dalam melaksanakan tugasnya sebagai pelayan publik. Hal ini menunjukkan bahwa kepuasan masyarakat merupakan faktor yang sangat penting, dalam menentukan keberhasilan penyelenggaraan pelayanan publik karena masyarakat adalah konsumen dari produk layanan yang dihasilkan oleh pemerintah.

Pelaksanaan pelayanan publik harus dapat memenuhi kebutuhan dan keinginan masyarakat untuk mencapai kepuasan masyarakat yang lebih baik. Jika pemerintah tidak dapat memenuhi kebutuhan dan keinginan masyarakat akan menyebabkan ketidakpuasan, sehingga kesetiaan masyarakat akan hilang. Untuk itu, pemerintah perlu meningkatkan pelayanan semaksimal mungkin kepada masyarakat.

Kualitas pelayanan publik telah menjadi fokus perhatian penting oleh pemerintah karena akan mempengaruhi kepuasan masyarakat. Ini dikarenakan seluruh pelayanan yang diberikan akan mendapat penilaian yang baik di masyarakat, sehingga kepuasan masyarakat akan muncul apabila kualitas pelayanan baik. Zeithaml, et al (2006) Kualitas pelayanan yang baik memiliki lima dimensi kualitas yang sering disebut dengan SERVEQUL (Service Quality) yang terdiri dari: 1) Reliabilitas (reliability), berkaitan dengan kemampuan pemberian pelayanan yang akurat sejak pertama kali tanpa membuat kesalahan apapun dan menyampaikan jasanya sesuai dengan waktu yang disepakati. 2) Daya tanggap (responssiveness), berkenaan dengan kesediaan dan kemampuan para karyawan untuk membantu para pelanggan dan merespon permintaan mereka, serta menginformasikan kapan jasa akan diberikan dan kemudian memberikan jasa secara tepat. 3) Jaminan (assurance), yakni perilaku para karyawan mampu membutuhkan kepercayaan pelanggan terhadap perusahaan dan perusahaan bisa menciptakan rasa aman pelanggannya. 4) Empati (empathy), berarti perusahaan memahami masalah pelanggannya dan bertindak demi kepentingan pelanggan, serta memberikan perhatian personal kepada para pelanggan dan memiliki jam operasi yang nyaman. 5) Bukti fisik (tangibles), berkenaan dengan daya tarik fasilitas fisik, perlengkapan, dan material yang digunakan perusahaan, serta penampilan karyawan.

\section{LANDASAN TEORI}

\section{Pengertian Kualitas Pelayanan}

Kedudukan aparatur pemerintah dalam pelayanan umum sangat strategis karena akan sangat menentukan sejauh mana pemerintah mampu memberikan pelayanan yang sebaik-baiknya kepada masyarakat, dengan demikian akan menentukan sejauhmana negara telah menjalankan perannya dengan baik sesuai dengan tujuan pendiriannya. Menurut Pemerintah dalam Surat Keputusan Menteri Pendayagunaan Aparatur Negara Nomor 81 Tahun 1993, pelayanan umum merupakan segala bentuk kegiatan yang dilaksanakan oleh instansi pemerintah tingkat pusat, daerah dan lingkungan BUMN/BUMD dalam bentuk barang atau jasa, baik dalam rangka pemenuhan kebutuhan masyarakat maupun dalam rangka pelaksanaan ketentuan perundangundangan.

Dari pengertian tersebut diatas dapat disimpulkan bahwa pelayanan publik merupakan segala bentuk kegiatan yang dilaksanakan oleh instansi pemerintah tingkat pusat, daerah dan lingkungan BUMN/BUMD dalam bentuk barang atau jasa dengan sistem, prosedur, dan metode 
tertentu dalam rangka memenuhi kebutuhan masyarakat atau individu sesuai dengan haknya secara baik dan memuaskan.

\section{Indeks Kepuasan Masyarakat}

Menurut Keputusan Menteri Pendayagunaan Aparatur Negara (KEPMENPAN) dan Reformasi Birokrasi Nomor 16 Tahun 2014 tentang Pedoman Survei Kepuasan Masyarakat terhadap Penyelenggaraan Pelayanan Publik, Indeks Kepuasan Masyarakat adalah data dan informasi tentang tingkat kepuasan masyarakat yang diperoleh dari hasil pengukuran secara kuantitatif dan kualitatif atas pendapat masyarakat dalam memperoleh pelayanan dari aparatur penyelenggara pelayanan public dengan membandingkan antara harapan dan kebutuuhannya.

\section{Tujuan dan Manfaat mengukur Kepuasan Masyarakat}

Tujuan pengukuran kepuasan masyarakat menurut Keputusan Menteri Pendayagunaan Aparatur Negara (KEPMENPAN) dan Reformasi Birokrasi Nomor 16 Tahun 2014 tentang Pedoman Survei Kepuasan Masyarakat terhadap Penyelenggaraan Pelayanan Publik adalah data dan informasi tentang tingkat kepuasan masyarakat yang diperoleh dari hasil pengukuran secara kuantitatif atas pendapat masyarakat dalam memperoleh pelayanan dari aparatur penyelenggara pelayanan publik dengan membandingkan antara harapan dengan kebutuhan.

\section{METODE PENELITIAN}

\section{Desain Penelitian}

Desain penelitian yang dilakukan dalam penelitian ini adalah survey karena informasi yang dikumpulkan dari responden menggunakan kuisioner. Dalam penelitian ini, peneliti mengumpulkan data informasi pokok dengan menggunaka kuisioner yang disebarkan kepada masyarakat yang melakukan kegiatan di bagian pelayanan pada Dinas Pengelolaan Keuangan dan Aset Daerah Kabupaten Bengkulu Selatan.

\section{Populasi dan Sampel}

Popolasi dalam penelitian ini adalah seluruh masyarakat yang melakukan kegiatan di pelayanan Dinas Pengelolaan Keuangan dan Aset DaerahKabupaten Bengkulu Selatan. Pengambilan sampel dilakukan secara accicental sampling yakni wajib pajak atau masyarakat yang datang untuk mengurus ke Dinas Pengelolaan Keuangan dan Aset DaerahKabupaten Bengkulu Selatan saat ditemui oleh peneliti. Responden yang terpilih ditetapkan minimal 150 orang dari jumlah penerima layanan Keputusan Menteri Pendayagunaan Aparatur Negara (KEPMENPAN) dan Reformasi Birokrasi Nomor 16 Tahun 2014 Sampel yang akan diambil oleh peneliti adalah sebanyak 150 responden dalam jangka waktu satu bulan.

\section{HASIL DAN PEMBAHASAN}

Penelitian ini dilakukan untuk mengetahui kualitas pelayanan pada bidang Dinas Pengelolaan Keuangan dan Aset Daerah Kabupaten Bengkulu Selatan berdasarkan 14 unsur prinsip pelayanan sebagaimana ditetapkan.

\section{Prosedur Pelayanan}

Berdasarkan hasil perhitungan dapat dilihat bahwa nilai rata-rata untuk unsur prosedur pelayanan adalah sebesar 2, 82. Pada unsur prosedur pelayanan Dinas Pengelolaan Keuangan dan Aset DaerahKabupaten Bengkulu Selatan responden menyatakan mudah, karena dilihat dari keterbukaan informasi, kejelasan alur dan kesederhanaan prosedur pelayanan sudah baik. Hal ini dikarenakan adanya informasi yang jelas dari petugas pelayanan baik berupa pelayanan tidak rumit, pendaftaran berkas sangat mudah, papan pengumuman, maupun informasi yang lain yang mudah 
diakses oleh masyarakat pengguna layanan. Berdasarkan interval skor yang ada maka dapat dikatakan bahwa kualitas dari unsur prosedur pelayanan dari bidang Dinas Pengelolaan Keuangan dan Aset DaerahKabupaten Bengkulu Selatan berada dalam kondisi baik.

\section{Persyaratan Pelayanan}

Berdasarkan hasil perhitungan dapat dilihat bahwa nilai rata-rata untuk unsur persyaratan pelayanan adalah sebesar 2, 84. Pada unsur persyaratan pelayanan Dinas Pengelolaan Keuangan dan Aset DaerahKabupaten Bengkulu Selatan responden menyatakan sesuai karena persyaratan untuk mendapatkan pelayanan menjadi sangat penting di lihat dari kepentingan masyarakat Kabupaten Bengkulu Selatan harus memenuhinya agar mendapatkan pelayanan seperti yang diharapkan. Bila sebelumnya persyaratan sudah disosialisasikan dengan baik dari petugas pelayanan, maka wajib pajak atau masyarakatpun akan dapat dengan mudah mempersiapkan baik dari administrasi maupun dari teknik pelaksanaannya. Maka dapat diambil kesimpulan bahwa pelayanan bidang Dinas Pengelolaan Keuangan dan Aset DaerahKabupaten Bengkulu Selatan telah memiliki persyaratan pelayanan yang memiliki kejelasan persyaratan baik secara teknis mauupun administrasi. Berdasarkan interval skor yang ada maka dapat dikatakan bahwa kualitas dari unsur persyaratan pelayanan dari bidang Dinas Pengelolaan Keuangan dan Aset DaerahKabupaten Bengkulu Selatan berada dalam kondisi baik.

\section{Kejelasan Petugas Pelayanan}

Berdasarkan hasil perhitungan dapat dilihat bahwa nilai rata-rata untuk unsur kejelasan petugas pelayanan adalah sebesar 2,88. Pada unsur kejelasan petugas pelayanan Dinas Pengelolaan Keuangan dan Aset DaerahKabupaten Bengkulu Selatan responden menyatakan jelas. Bagi masyarakat, kejelasan mengenai keberadaan petugas pelayanan dan kemudahan untuk menemuinya sangat berguna untuk memperlancar proses dari penyelesaian berkas. Begitupun dengan kejelasan identitas dan tanggung jawab memberikan keterangan yang jelas kepada masyarakat. Dari hasil analisa tabel 4.6 telah memberikan gambaran bahwa kejelasam petugas pelayanan di bidang Dinas Pengelolaan Keuangan dan Aset DaerahKabupaten Bengkulu Selatan sudah memiliki sebagian kesesuaian pengertian dari kejelasan petugas pelayanan yaitu dari segi keberadaan dan kepastian petugas yang memberikan pelayanan. Berdasarkan interval skor yang ada maka dapat dikatakan bahwa kualitas dari unsur kejelasan petugas pelayanan dari bidang Dinas Pengelolaan Keuangan dan Aset DaerahKabupaten Bengkulu Selatan berada dalam kondisi baik.

\section{Kedisiplinan Petugas Pelayanan}

Berdasarkan hasil perhitungan dapat dilihat bahwa nilai rata-rata untuk unsur keamanan pelayanan adalah sebesar 2, 70. Kedisiplinan petugas pelayanan, yaitu kesungguhan petugas dalam memberikan pelayanan terutama terhadap konsistensi waktu kerja sesuai dengan ketentuan yang berlaku. Pada unsur kedisiplinan petugas pelayanan Dinas Pengelolaan Keuangan dan Aset DaerahKabupaten Bengkulu Selatan responden menyatakan baik. Karena di lihat dari kredibelitas dan ketepatan waktu dalam menyelesaikan pelayanan sudah baik. Hal ini sudah sesuai dengan standar operasional prosedur (SOP) bidang Dinas Pengelolaan Keuangan dan Aset DaerahKabupaten Bengkulu Selatan mengenai waktu pelayanan dalam setiap pelayanan kepada masyarakat. Dari data yang diperoleh maka didapat hasil penelitian bahwa kedisiplinan petugas pelayanan bidang Dinas Pengelolaan Keuangan dan Aset DaerahKabupaten Bengkulu Selatan disiplin meskipun masih banyak terdapat kekurangan yang harus menjadi fokus utama dalam pembenahan pelayanan bidang Dinas Pengelolaan Keuangan dan Aset DaerahKabupaten Bengkulu Selatan yang berhubungan dengan disiplim petugas pelayanan. Berdasarkan interval skor yang ada maka dapat dikatakan bahwa kualitas dari unsur kedisiplinan petugas pelayanan dari bidang Dinas Pengelolaan Keuangan dan Aset DaerahKabupaten Bengkulu Selatan berada dalam kondisi baik. 


\section{Tanggung Jawab Petugas Pelayanan}

Berdasarkan hasil perhitungan dapat dilihat bahwa nilai rata-rata untuk unsur tanggung jawab petugas pelayanan adalah sebesar 2,70 . Tanggung jawab petugas pelayanan yakni kejelasan wewenang dan tanggung jawab petugas dalam penyelenggaraan dan penyelesaian pelayanan. Dari tabel 4.6 dapat dilihat bahwa pelayanan dari bidang Dinas Pengelolaan Keuangan dan Aset DaerahKabupaten Bengkulu Selatan melaksanakan pelayanan akan fungsi dan tugasnya masingmasing yang telah dilaksanakan dengan baik.. Berdasarkan interval skor yang ada maka dapat dikatakan bahwa kualitas dari unsur tanggung jawab petugas pelayanan dari bidang Dinas Pengelolaan Keuangan dan Aset DaerahKabupaten Bengkulu Selatan berada dalam kondisi baik.

\section{Keamampuan Petugas Pelayanan}

Berdasarkan hasil perhitungan dapat dilihat bahwa nilai rata-rata untuk unsur keamanan pelayanan adalah sebesar 2,79. Pada unsur kemampuan petugas pelayanan Dinas Pengelolaan Keuangan dan Aset DaerahKabupaten Bengkulu Selatan responden menyatakan mampu dalam menyelesaikan pelayanan. kemampuan petugas pelayanan yakni tingkat keahlian dan keterampilan yang dimiliki petugas dalam memberikan atau menyelesaikan pelayanan kepada masyarakat. Sementara dalam standar pelayanan disebutkan Kompetensi petugas pemberi pelayanan harus ditetapkan dengan tepat berdasarkan pengetahuan, keahlian, keterampilan, sikap, dan perilaku yang dibutuhkan. Dari hasil analisis dapat dilihat bahwa dari kemampuan petugas pelayanan bidang baik secara fisik, intelektual dan administrasi. Kemampuan dari SDM yang ada merupakan orang yang ahli dan berkompeten dibidangnya dan juga memiliki pengalaman yang cukup lama. Berdasarkan interval skor yang ada maka dapat dikatakan bahwa kualitas dari unsur kemampuan petugas pelayanan bidang Dinas Pengelolaan Keuangan dan Aset DaerahKabupaten Bengkulu Selatan berada dalam kondisi baik.

\section{Kecepatan Pelayanan}

Berdasarkan hasil perhitungan dapat dilihat bahwa nilai rata-rata untuk unsur keamanan pelayanan adalah sebesar 2,56. Pada unsur kecepatan pelayanan Dinas Pengelolaan Keuangan dan Aset DaerahKabupaten Bengkulu Selatan responden menyatakan cepat dalam menyelesaikan pelayanan. Kecepatan pelayanan yaitu target waktu pelayanan dapat diselesaikan dalam waktu yang telah ditentukan oleh unit penyelenggara pelayanan di bidang Dinas Pengelolaan Keuangan dan Aset DaerahKabupaten Bengkulu Selatan. Dari unsur ini dapat dilihat dari kemampuan petugas pelayanan dalam ketepatan waktu pada proses pelayanan dam tingkat keterbukaan waktu penyelesaian pelayanan. Bidang telah menerapkan standar waktu pelayanan untuk masing- masing pelayanan. Jadi untuk setiap pelayanan waktu penyelesaian sudah baku tetapi sebelum mendapatkan pelayanan wajib pajak atau masyarakat terlebih dahulu harus menunggu antrian. Namun, jika dilihat dari interval skor yang ada maka dapat dikatakan bahwa kualitas dari unsur kecepatan pelayanan di Dinas Pengelolaan Keuangan dan Aset DaerahKabupaten Bengkulu Selatan berada dalam kondisi baik.

\section{Keadilan Mendapatkan Pelayanan}

Keadilan mendapatkan pelayanan yaitu pelaksanaan pelayanan dengan tidak membedakan golongan atau status masyarakat. Bersarkan hasil perhitungan dapat dilihat bahwa nilai rata-rata untuk unsur keadilan mendapatkan pelayanan adalah sebesar 2,52. Pada unsur keadilan mendapatkan pelayanan Dinas Pengelolaan Keuangan dan Aset DaerahKabupaten Bengkulu Selatan responden menyatakan kurang adil dalam memberikan pelayanan. Keadilan memberikan pelayanan yakni pelaksanaan pelayanan dengan tidak membedakan golongan/ status masyarakat yang dilayani. Menurut Carlson dan Schwartz (dalam Frederik Mote, 2008) menyatakan bahwa ukuran komprehensip untuk sevequal sektor publik keadilan yaitu ukuran tingkat dimana masyarakat percaya bahwa pelayanan pemerintah disediakan sama untuk semua orang. Dari unsur 
dapat dilihat dari petugas pelayanan memberikan pelayanan kepada masyarakat yang datang. Terkadang dalam memberikan pelayanan petugas tidak memperhatikan antrian. Jika ada keluarga atau teman petugas pelayanan datang untuk mengurus maka teman atau keluarganya yang didahulukan untuk memperoleh pelayanan dibandingkan dengan masyarakat yang telah antri. Dari tabel 1 pada unsur keadilan mendapatkan pelayanan, dapat dilihat pendapat dari responden yaitu tidak adil sebanyak 16 responden, cukup adil sebanyak 59 responden, adil sebanyak 60 responden, sangat adil sebanyak 15 responden. Disini dapat dilihat kurangnya kemerataan atau cakupan dalam pelaksanaan pelayanan. Jika dilihat dari interval skor yang ada maka dapat dikatakan bahwa kualitas dari unsur keadilan mendapatkan pelayanan dari bidang Dinas Pengelolaan Keuangan dan Aset DaerahKabupaten Bengkulu Selatan berada dalam kondisi kurang baik.

\section{Kesopanan dan Keramahan Petugas}

Berdasarkan hasil perhitungan dapat dilihat bahwa nilai rata-rata untuk unsur kesopanan dan keramahan adalah sebesar 2,66. Kesopanan dan keramahan petugas merupakan sikap dan perilaku petugas dalam memberikan pelayanan kepada masyarakat secara sopan dan ramah serta saling menghargai dan menghormati. Pada unsur kesopanan dan keramahan petugas pelayanan Dinas Pengelolaan Keuangan dan Aset DaerahKabupaten Bengkulu Selatan responden menyatakan sopan dan ramah. Karena di lihat dari tingkat kesopanan dan keramahan petugas dalam memberikan pelayanan serta penghormatan dan penghargaan antara petugas dan masyarakat atau wajib pajak. Berdasarkan interval skor yang ada maka dapat dikatakan bahwa kualitas dari unsur kesopanan dan keramahan petugas pelayanan bidang Dinas Pengelolaan Keuangan dan Aset DaerahKabupaten Bengkulu Selatan berada dalam kondisi baik.

\section{Kewajaran Biaya Pelayanan}

Kewajaran biaya adalah keterjangkauan masyarakat terhadap besarnya biaya yang ditetapkan oleh unit pelayanan. Berdasarkan Hasil Perhitungan dapat dilihat bahwa nilai rata-rata untuk unsur kewajaran biaya pelayanan adalah sebesar 2,30. Dilihat dari segi kewajaran biaya pelayanan Dinas Pengelolaan Keuangan dan Aset DaerahKabupaten Bengkulu Selatan responden menyatakan kurang wajar. Berdasarkan interval skor yang ada maka dapat dikatakan bahwa kualitas dari unsur kewajaran biaya pelayanan dari bidang Dinas Pengelolaan Keuangan dan Aset DaerahKabupaten Bengkulu Selatan berada dalam kurang baik. Yang dimaksud kewajaran biaya pelayanan ini adalah apabila SPPT yang telah jatuh tempo belum dibayar akan timbul denda sebesar $2 \%$ dari pajak terhutang setiap bulannya.

\section{Kepastian Biaya Pelayanan}

Kepastian biaya yaitu kesesuaian antara biaya yang dibayarkan dengan biaya yang telah ditetapkan. Berdasarkan Hasil Perhitungan dapat dilihat bahwa nilai rata-rata untuk unsur kepastian biaya pelayanan adalah sebesar 2,15. Dilihat dari segi kepastian biaya pelayanan Dinas Pengelolaan Keuangan dan Aset DaerahKabupaten Bengkulu Selatan responden menyatakan kurang sesuai. Karena dalam mengurus.

\section{Kepastian Jadwal Pelayanan}

Berdasarkan Hasil Perhitungan dapat dilihat bahwa nilai rata-rata untuk unsur kepastian jadwal pelayanan adalah sebesar 2,36. Pada unsur ini bidang pelayanan Dinas Pengelolaan Keuangan dan Aset DaerahKabupaten Bengkulu Selatan responden menyatakan kurang tepat. Karena dalam penyelesaian berkas tidak dapat dipastiakan dengan tepat oleh petugas pelayanan. Hal ini di sebabkan adanya hambatan lain dalam pelaksanaan tugas. Berdasarkan interval skor yang ada maka dapat dikatakan bahwa kualitas dari unsur kepastian jadwal pelayanan dari bidang Dinas Pengelolaan Keuangan dan Aset DaerahKabupaten Bengkulu Selatan berada dalam kondisi kurang baik. 


\section{Kenyamanan Lingkungan}

Berdasarkan Hasil Perhitungan dapat dilihat bahwa nilai rata-rata untuk unsur kenyamanan pelayanan adalah sebesar 2,63. Dilihat dari segi kenyamananlingkungan pelayanan Dinas Pengelolaan Keuangan dan Aset DaerahKabupaten Bengkulu Selatan responden menyatakan nyaman. Karena di tempat pelayanan terdapat ruang tunggu yang nyaman dengan dilengkapi fasilitas tambahan yang baik seperti tempat duduk untuk mengantri, televisi, AC dan toilet yang bersih. Dengan demikian masyarakat merasa nyaman untuk menunggu giliran untuk mendapatkan pelayanan Dinas Pengelolaan Keuangan dan Aset DaerahKabupaten Bengkulu Selatan. Berdasarkan interval skor yang ada maka dapat dikatakan bahwa kualitas dari unsur kenyamanan pelayanan dari bidang Dinas Pengelolaan Keuangan dan Aset DaerahKabupaten Bengkulu Selatan berada dalam kondisi baik

\section{Keamanan Pelayanan}

Berdasarkan Hasil Perhitungan dapat dilihat bahwa nilai rata-rata untuk unsur keamanan pelayanan adalah sebesar 2,63. Dilihat dari segi keamanan lingkungan pelayanan baik di dalam maupun diluar (tempat parkir kendaraan) di Dinas Pengelolaan Keuangan dan Aset DaerahKabupaten Bengkulu Selatan responden menyatakan aman. Karena di sekitar lingkungan pelayanan terdapat beberapa orang petugas keamanan, yang setiap saat mengawasi lingkungan sekitar pelayanan sehingga masyarakat merasa tenang untuk mendapatkan pelayanan. Berdasarkan interval skor yang ada maka dapat dikatakan bahwa kualitas dari unsur keamanan pelayanan dari bidang Dinas Pengelolaan Keuangan dan Aset DaerahKabupaten Bengkulu Selatan berada dalam kondisi baik.

\section{KESIMPULAN DAN SARAN}

\section{Kesimpulan}

1. Secara keseluruhan penilaian masyarakat terhadap pelayanan pada Dinas Pengelolaan Keuangan dan Aset DaerahKabupaten Bengkulu Selatan berada dalam kategori baik. Hal ini dapat dilihat dari besaran nilai IKM sebesar 65, yang berarti bahwa kinerja dari bidang Dinas Pengelolaan Keuangan dan Aset DaerahKabupaten Bengkulu Selatan adalah baik. Karena nilai tersebut berada pada kelas interval konversi IKM antara 64,51 sampai dengan 82,35 dengan kategori kelas baik (B).

2. Dari 14 unsur yang nilai, terdapat 10 unsur yang bernilai baik, yaitu unsur prosedur pelayanan dengan nilai sebesar 2,82, unsur persyaratan pelayanan dengan nilai sebesar 2,84, unsur kejelasan petugas pelayana dengan nilai sebesar 2,88 , unsur kedisiplinan petugas pelayanan dengan nilai sebesar 2,70, unsur tanggung jawab petugas pelayanan dengan nilai sebesar 2,70, unsur kemampuan petugas pelayanan dengan nilai sebesar 2,79, unsur kecepatan pelayanan dengan nilai sebesar 2,56, unsur kesopanan dan keramahan petugas dengan nilai sebesar 2,66, unsur kenyamanan lingkungan dengan nilai sebesar 2,63, dan unsur keamanan pelayanan dengan nilai sebesar 2,63. Kemudian ada 4 unsur yang mendapat penilaian kurang baik yaitu unsur keadilan mendapatkan pelayanan dengan nilai sebesar 2,52, unsur kewajaran biaya pelayanan dengan nilai sebasar 2,30, unsur kepastian biaya pelayanan dengan nilai sebesar 2,15, dan unsur kepastian jadwal pelayanan dengan nilai sebesar 2,36.

\section{Saran}

Untuk menjaga kepercayaan masyarakat dalam pelayanan pengurusan Dinas Pengelolaan Keuangan dan Aset DaerahKabupaten Bengkulu Selatan yang berkualitas dan memperhatikan kepentingan masyarakat. Maka ada beberapa hal yang harus dipertimbangkan untuk memperbaiki 14 unsur perinsip pelayanan sebagaimana ditetapkan dalam Keputusan Menteri Pendayagunaan 
Aparatur Negara (KEPMENPAN) dan Reformasi Birokrasi Nomor 16 Tahun 2014 yang masih kurang baik yaitu Keadilan mendapatkan pelayanan, Kewajaran biaya pelayanan, Kepastian biaya pelayanan dan Kepastian jadwal pelayanan sehingga kedepan pelayanan bidang Dinas Pengelolaan Keuangan dan Aset Daerah Kabupaten Bengkulu Selatan menjadi lebih baik lagi.

\section{DAFTAR PUSTAKA}

AR, Mustamir. 2011. Kualitas Pelayanan Pajak Oleh Pegawai Kantor Pelayanan Pajak Pratama Bengkulu. Tesis. Universitas Bengkulu.

Azis Mahyudin, Karona Cahya Susena, \& Ermy Wijaya. (2021). Analysis of the Community Satisfaction Index (IKM) on the Quality of Library Services at the University of Dehasen Bengkulu. Jurnal Ekonomi, Manajemen, Bisnis Dan Akuntansi Review, 1(1), 47-54.

Batubara, H A. 2006. Strategi Meningkatkan Kualitas Pelayanan Prima. Jurnal Pemberdayaan Komunitas. Volume 5 Nomor 1 hal. 81

Cahyono, Giri. 2008. Pengaruh Kualitas Pelayanan Dan Harga Pelayanan Terhadap Kepuasan Masyarakat. Tesis. Universitas Terbuka.

Gaspersz, Vincent. 1997. Manajemen Kualitas: Penerapan Konsep Vincent dalam Manajemen Bisnis Total. Gramedia Pustaka Utama. Jakarta. 1997. Manajemen Kualitas dalam Industri Jasa. PT. Gramedia Pustaka. Jakarta. 1997. Total Quality Management. PT. Gramedia Pustaka. Jakarta.

Goetsch, David L, Dan Stanley B. Davis. 2002. Pengantar Manajemen Mutu 2. Edisi Bahasa Indonesia, Jakarta: PT Prenhalindo.

Keputusan Menteri Pendayagunaan Aparatur Negara (KEPMENPAN) dan Reformasi Birokrasi Nomor 16 Tahun 2014 tentang Pedoman Survei Kepuasan Masyarakat terhadap Penyelenggaraan Pelayanan Publik.

Keputusan Menteri Pendayagunaan Aparatur Negara Nomor 63/KEP/M.PAN/7/2003 tentang Pedoman Umum Penyelenggaraan Pelayanan Publik.

Mote, Frederik. 2008. Analisis Indeks Kepuasan Masyarakat (IKM) Terhadap Pelayanan Publik Di Puskesmas Ngesrep Semarang. Universitas Diponegoro.

Mustafa, Ardi. 2014. Analisis Pengaruh Kualitas Pelayanan Terhadap Kepuasan Pengguna Spektrum Frekuensi Radio Bengkulu. Tesis. Universitas Bengkulu.

Nela Puspita Sari, Karona Cahya Susena, \& Nia Indriasari. (2020). Measuring the Level of Community Satisfaction with Government Services in Pino Raya District, South Bengkulu Regency. Jurnal Ekonomi, Manajemen, Akuntansi Dan Keuangan, 1(4), 259-271.

Ningsih, Wahyu dan Riska. 2015. Pengaruh Variabel Kualitas Pelayanan Terhadap Kepuasan Masyarakat Pada Kantor Pelayanan Perizinan Kabupaten Bengkulu Selatan. Tesis. Universitas Bengkulu.

Sianta, J. L., Susena, K. C., \& Nengsih, M. K. (2020). The Analysis Of Community Satisfaction Index (Smi) On Public Services In Sidomulyo Kelurahan Office Bengkulu City. JURNAL EMAK, 1(3), 172181.

Singarimbun, Musri dan Effendy, Sofyan. 1996. Metode Penelitian Survey. Jakarta: Pustaka.

Sugiyono. 2007. Metode Penelitian Bisnis. Cetakan Kesembilan. Bandung: Alfabeta.

Supranto, J. 2000. Pengukuran Tingkat Kepuasan Pelanggan. Cetakan Pertama. Jakarta: Rineka Cipta.

Surat Edaran Menteri Pendayagunaan Aparatur Negara Nomor 81 tahun 2003 tentang Pelayanan Publik.

Tjiptono, Fandy. 2005. Pemasaran Jasa. Yogyakarta: Andi Ofset.

Zeithaml, Valerie; Bitner M.j; Gremler, Dwayne. 2006. Service Marketing. Singapore: McGraw-Hill International Edition. 